

\title{
EFFECT OF CONSUMER PROTECTION FUNCTION ON FINANCIAL PERFORMANCE OF SACCOS IN KENYA
}

\author{
${ }^{1}$ Jackson Mnago Ndungo' ${ }^{2}$ Dr. Olweny Tobias and ${ }^{3}$ Dr. Memba Florence \\ ${ }^{1}$ Jomo Kenyatta University of Agriculture and Technology, Kenya \\ ${ }^{2}$ Jomo Kenyatta University of Agriculture and Technology, Kenya \\ ${ }^{3}$ Jomo Kenyatta University of Agriculture and Technology, Kenya \\ E-mail of corresponding author: ndungojackson@yahoo.com
}

\begin{abstract}
Purpose: The study sought to determine the effect of consumer protection function on financial performance of SACCOs in Kenya.

Methodology: The study adopted a descriptive research design. The target population comprised of registered 181 deposit-taking SACCOs as at $31^{\text {st }}$ December 2014 and the three licensed CRBs in Kenya. Stratified random sampling was used in the study, where SACCOs were grouped into five respective strata which were then randomly selected. The SACCOs were grouped into five respective strata of government based, teachers based, farmers based, private institutions based and community based. The study sampled 135 of the 181 (74.5\%) licensed deposit taking SACCOs since these were the only licensed deposit-taking SACCOs by 2014. The choice of the licensed deposit taking SACCOs in Kenya was very objective since it was possible to obtain information that is representative of Kenya. In addition, SACCOs form the smaller arm in the financial sector and in most cases deals with a larger group of clients from the informal sector as opposed to other financial institutions like banks. Both primary and secondary data were analyzed using SPSS software, and statistics generated included descriptive statistics and inferential statistics. The particular descriptive statistics used included frequencies and percentages while the particular inferential statistics included Pearson correlation analysis and regression. Correlation analysis was used to establish relationships between the consumer protection function and financial performances. Regression analysis was used to establish the significance of the variables and the degree of causal effect of the independent variables on the dependent variable. The hypotheses testing were conducted using simple regression model.
\end{abstract}

Findings: From the data analysis the study concluded that there was a significant and positive relationship between consumer protection function and financial performance thus the existence of credit reference bureaus was suitable for improving financial performance of SACCOs. This implies that that Credit reference bureaus have led to consumer protection and increased customers' rights. Similarly, credit reference bureaus have led to assumption that borrowing is a right regardless of capabilities. Credit reference bureaus have reduces undesired monopolistic actions of lenders. Lastly, credit reference bureaus have led to reduced bad "culture" on loan repayment. 
Recommendation: The study recommended that lenders should ensure that they have accurate information before listing the unworthy borrowers to avoid unnecessary legal battles which may affect performance as a measure for customer rights protection.

Keywords: Consumer protection, lender, Credit Reference Bureaus, information sharing, defaulters, financial performance, SACCOs.

\subsection{INTRODUCTION}

\subsection{Background and Research Gap}

The existence of information asymmetry between lenders and borrowers calls for the need for the establishment of Credit Reference Bureau services in the financial institutions. Credit is more abundant when borrowers and lenders benefit from credit information institutions (Lin, Ma, \& Song, 2012). It is difficult to have accurate information on the financial ability of prospective borrowers and even more difficult to have accurate information on their credit history. Information asymmetry makes it extremely difficult for lenders to assess the borrowers`credit worthiness and their ability to repay the loans with attached interest. In most developed economies, credit reporting is a critical part of the financial system but in developing countries credit reporting is generally weak or even absent resulting to non-performing loans.

Credit reference bureau (CRB) is a company that collects information from various sources and provides consumer credit information on individual consumers for a variety of uses. It is an organization providing detailed information on a person's credit history, including information on their identity, credit accounts and loans, bankruptcies and late payments and recent inquiries. Other information shared include: proven frauds and forgeries; cheque kiting; false declarations and statements; receiverships, bankruptcies and liquidations; credit default and late payments; use of false securities; and misapplication of borrowed funds. Therefore consumer credit reporting has evidently become the most extensively used instrument employed by lenders to underwrite decisions on borrowing regarding to evaluation of a consumer`s credit application and his or her credit worthiness; on the understanding that the best predictor of future behavior is past behavior (Siwela, 2011).

The early credit reporting started sometime back: in Europe 1960`s, in United State 1970`s, and Hong Kong and Australia 1980`s and 1990`s respectively. In USA, the Fair Credit Reporting Act was enacted to regulate the credit information sharing mechanism. Studies conducted by Keeton \& Morris (2007) on a sample of nearly 2,500 United States commercial banks indicate that large portion of loan losses recorded by the banks ascribe to adverse local economic conditions along with the poor performance of certain sectors.

Bercoff, Giovanni and Grimard (2012) categorize causes of credit default to Bank specific and Macroeconomic conditions. Throughout the developing world, the growing availability of consumer credit and the growing competition between financial institutions have made the necessity of credit information sharing all the more apparent. Marcucci and Quagliariello (2011) found that the business cycle affects the NPL ratio for a large panel of Italian banks over the period 1985 to 2002. However, the extent and efficiency of information sharing mechanisms vary greatly between countries and continents. Africa remains the region of the world with the least developed credit information systems, yet the exploding financial sectors in many African 
countries have sparked interest in the feasibility of the creation of credit bureaus to help manage borrower risk under heightened competition. However, the existence of inherently weak credit culture amongst African nations has resulted to large numbers of unpaid loans.

In Kenya the operations, establishment, licensing, governance and management of CRBs, is provided through the banking Act, 2008. Establishment and licensing of credit reference bureaus in Kenya, is through an entity incorporated as a limited company under the companies Act and application for a license is made through the central bank of Kenya. Currently, there are three credit reference bureaus: Transunion Credit Reference Bureau Ltd, Metropol Credit Reference Bureau Ltd and Credit Info Credit Reference Bureau Ltd which are registered by the Central Bank of Kenya (CBK, 2013) to access credit data. In Kenya, aspirants seeking political office or any public post are expected to obtain certificates that confirm their creditworthiness under the requirements of the Leadership and Integrity Act, 2012 on financial obligations.

The Kenya Credit Information Sharing report (2012) specified three roles played by CRBs: first, they enable lenders to lend to more and better risk clients thereby avoiding dead beats as well as determine better and lower the bad loan spread that they need to cover expected losses of credit to good payers. Secondly, credit bureaus reduce the borrowing cost by forcing creditors to be more competitive for good borrowers. Those lower costs for good credit risks motivate those borrowers to be more careful with repayment. Thirdly, credit bureaus reduce moral hazard by developing a credit culture where they operate as borrowers become aware that credit market becomes aware of their credit history and rewards or punishes them accordingly.

The enactment of the SACCO Societies Act, made provisions for licensing, regulation, supervision, promotion of SACCO Societies and establishment the SACCO Societies Regulatory Authority (Kenya Gazette supplement No 8; SACCO Societies Act, 2008). Sacco Societies Regulatory Authority (SASRA) is mandated under Section 28 of the Sacco Societies Act, 2008 to license deposit-taking Sacco Societies. Under the Act, SACCOs are required to comply with and maintain minimum capital adequacy requirements, maintain minimum requirement of liquid assets of its member borrowings, engage in businesses as prescribed by the authority, conform to financial reporting as per the society.

The Act and Regulations include clear standards regarding, among others, capital, liquidity, the extent of external borrowing, asset categorization and provisioning, maximum loan size, and insider lending. SACCOs are also subject to adhering to monthly (capital adequacy, liquidity, and deposits) reporting, quarterly (risk classification of assets and loan loss provisioning, investment returns, financial performance) and annual (audited financial statements) reporting requirements to SASRA (SASRA, 2012).

The SACCO Board of directors is democratically elected from amongst the members. SACCOs are also different from MFI in the sense that SACCOs have an intermediate broad array of financial services beyond credit. Unlike MFIs, they mobilize voluntary public deposits from their members on a much greater scale and are community-owned by individuals with equal ownership. Lending is the main business of financial institutions with loans forming the main source of revenue for SACCOs (Kwambai \& Wandera, 2013). 


\subsection{Statement of the Problem}

Due to the existence of information asymmetry, the licensing of credit reference bureaus by SASRA continue to gain interest in SACCOs especially those in business of deposit-taking commonly known as Front Office Service Activity (FOSA). The total assets of SACCOs grew from 257 billion to 301.5 billion while total deposits increasing from 182.7 billion to 205.9 billion from December 2013 to December 2014 financial years (SASRA, 2014). SACCOs have improved lives of many by grating loans and offering direct and indirect employment opportunities. However, defaults on loan repayments pose the greatest risk to stability of the multi-billion-shilling savings and credit co-operative (SACCO) movement (CBK, 2012).

The risk of defaults on personal loans granted by SACCO's is high, as the debts are secured only by member guarantors. Many SACCOs have collapsed in Kenya since 1986 due to nonperforming loans as evidenced by gazette notice No.15698 of $28^{\text {th }}$ November, 2013 which indicated that Bookies SACCO Society Limited was under liquidation. In the recent years SACCOs have moved to Front Office Operations thus operating like commercial banks. What they do, how they do it and the consequences of their actions need to be understood clearly (SASRA, 2014).

Locally, Segita, Limo, Kibati, \& Muhanji (2014) reviewed the asymmetry information on CRBs for banks in Kenya; Gitahi (2013) studied on the effect of CRBs on NPLs in commercial banks in Kenya and Gaitho (2013) reviewed the role of credit reference bureau on credit access, a survey of commercial banks in Kenya. The hidden actions of lenders and borrowers in their credit transactions have resulted to the current financial crisis faced by SACCOs. Therefore, the effect of consumer protection functions on financial performance of deposit-taking SACCOs in Kenya would address the gap.

\subsection{Objectives of the Study}

To determine the effect of consumer protection function on financial performance of SACCOs in Kenya.

\subsection{RESEARCH METHODOLOGY}

The study adopted a descriptive research design which generally describes the characteristics of a particular situation, event or case. The target population comprised of registered 181 deposittaking SACCOs as at 31 ${ }^{\text {st }}$ December 2014 (SASRA, 2014) and the three licensed CRBs in Kenya. The sampling frame used was the list of all the 135 licensed deposit taking SACCOs as at $31^{\text {st }}$ December 2014 (SASRA, 2014). The choice of the licensed deposit taking SACCOs in Kenya was very objective since it was possible to obtain information that is representative of Kenya. In addition, SACCOs form the smaller arm in the financial sector and in most cases deals with a larger group of clients from the informal sector as opposed to other financial institutions like banks.

The study used stratified random sampling where the SACCOs were grouped into their respective strata and randomly selected. The SACCOs were grouped into five respective strata of government based, teachers based, farmers based, private institutions based and community based. The study sampled 135 of the 181 (74.5\%) licensed deposit taking SACCOs since these 
were the only licensed deposit-taking SACCOs by 2014. Therefore the sample size of the study was 135 respondents.

Table 1: Sample Size

\begin{tabular}{lcc}
\hline Categories & Population & Sample \\
\hline Government based DTSs & 42 & 31 \\
Teachers based DTSs & 42 & 31 \\
Farmers based DTSs & 58 & 43 \\
Private institutions based DTSs & 16 & 12 \\
Community based DTSs & 23 & 17 \\
Total & $\mathbf{1 8 1}$ & $\mathbf{1 3 5}$ \\
\hline
\end{tabular}

Source: SASRA 2014

The study used both primary and secondary data which was largely quantitative and descriptive in nature. Data collected from secondary sources were available from the CRBs, published journals, annual reports and financial reports. Primary data was obtained from the original sources using questionnaires. The study used a structured questionnaire to collect data on credit access function, information sharing function, consumer protection function, and risk management.

The primary collected using questionnaires and the secondary data were subjected to quantitative analysis using SPSS, version 20. SPSS offers extensive data handling capacity and numerous statistical routine that can analyze small to large data statistics (Donald \& Tromp, 2006). The statistics generated included descriptive statistics and inferential statistics. The particular descriptive statistics used included frequencies and percentages while the particular inferential statistics included Pearson correlation analysis and regression.

Correlation analysis was used to establish the relationships between the consumer protection function and financial performance. Regression analysis was used to establish the significance of the variables and the degree of causal effect of the independent variables on the dependent variable. The hypotheses testing was conducted using simple regression model and thus was tested on the objective as shown below;

Objective: Effect of consumer protection function on financial performance;

$\mathrm{Y}=\beta_{0}+\beta_{1} \mathrm{X}_{1}+\varepsilon$

Where

$\mathrm{X}_{1}=$ Consumer Protection Function

$\mathrm{Y}=$ Financial Performance 


\subsection{RESEARCH FINDINGS AND DISCUSIONS}

\subsection{Response Rate}

The number of questionnaires that were administered were 135 and a total of 110 questionnaires were properly filled and returned. Out of the 135 questionnaires administered 110 were filled and returned representing 81.5 percent. The response rate result is shown in Table 2.

\section{Table 2: Response Rate}

\begin{tabular}{lcc}
\hline Response & Frequency & Percent \\
\hline Returned & 110 & $81.5 \%$ \\
Unreturned & 25 & $18.5 \%$ \\
Total & $\mathbf{1 3 5}$ & $\mathbf{1 0 0 \%}$ \\
\hline
\end{tabular}

\subsection{Demographic Information}

The study sought to establish the demographic characteristics such as of the category/type of the Sacco, year of existence and licensed year.

\subsubsection{Categories of Sacco}

The respondents were asked to indicate their type of Sacco. Results are presented in table 3.

\section{Table 3: Categories of Sacco}

\begin{tabular}{lcc}
\hline Type of Sacco & Frequency & Percent \\
\hline Government based & 30 & 27.2 \\
Teachers based & 10 & 9.0 \\
Farmers based & 19 & 17.2 \\
Private institutions based & 27 & 24.5 \\
Community based & 24 & 21.8 \\
Total & $\mathbf{1 1 0}$ & $\mathbf{1 0 0}$ \\
\hline
\end{tabular}

Table 3 show five categories of deposit-taking SACCOs namely government based deposittaking SACCOs, teachers based, farmers based deposit-taking SACCOs, private institutions based deposit-taking SACCOs and community based deposit-taking SACCOs. Government institutions based deposit-taking SACCOs had the largest share of 27.2 percent, private based SACCOs had 24.5 percent followed by community based with 21.8 percent, farmers based had 17.2 percent while teachers based had the smallest share of 9.0 percent. This could mean that government institutions have the largest number of employees in the country compared to the other sectors.

\subsubsection{Years of existence}

The respondents were asked to indicate the years of existence of their deposit taking SACCOs. Results are presented in table 4. 
Table 4: Years of Existence

\begin{tabular}{lcc}
\hline Duration & Frequency & Percent \\
\hline $11-20$ years & 17 & 15.5 \\
Above 20 years & 93 & 84.5 \\
Total & $\mathbf{1 1 0}$ & $\mathbf{1 0 0}$ \\
\hline
\end{tabular}

Table 4 shows that $84.5 \%$ of the respondents who were the majority indicated that their deposit taking SACCOs has been in existence for over 20 years while only $15.5 \%$ indicated that they have been existence for between 11-20 years.

\subsubsection{Number of Years the SACCO was licensed in Deposit-taking Business}

The respondents were requested to indicate Number of Years their SACCOs were licensed in Deposit-taking Business. Results are presented in table 5.

Table 5: Number of Years the SACCO was licensed in Deposit-taking Business Number of Years $\quad$ Frequency Percent

\begin{tabular}{lcc}
\hline Less than 1 year & 12 & 10.9 \\
2 to 5 years & 75 & 68.2 \\
More than 5 years & 23 & 20.9 \\
Total & $\mathbf{1 1 0}$ & $\mathbf{1 0 0 . 0}$ \\
\hline
\end{tabular}

Results in Table 5 shows that 10.9 percent of the sampled SACCOs were licensed for less than one year, 68.9 percent licensed within two to five years while 20.9 percent were licensed for more than five years as shown in table 5. This could indicate that many SACCOs registered after 2010 when the credit reference bureaus started and the SACCOs were aware of the need to be registered in the credit bureaus to control defaults rate thus improving their financial performance.

4.3 Effect of Consumer Protection Function on financial performance of SACCOs in Kenya.

The study sought to establish the effect of consumer protection function on financial performance of SACCOs in Kenya.

\section{Descriptive statistics}

The study sought to examine the effect of consumer protection function on the financial performance of SACCOs. Results are presented in table 6. 
Table 6: Consumer protection function

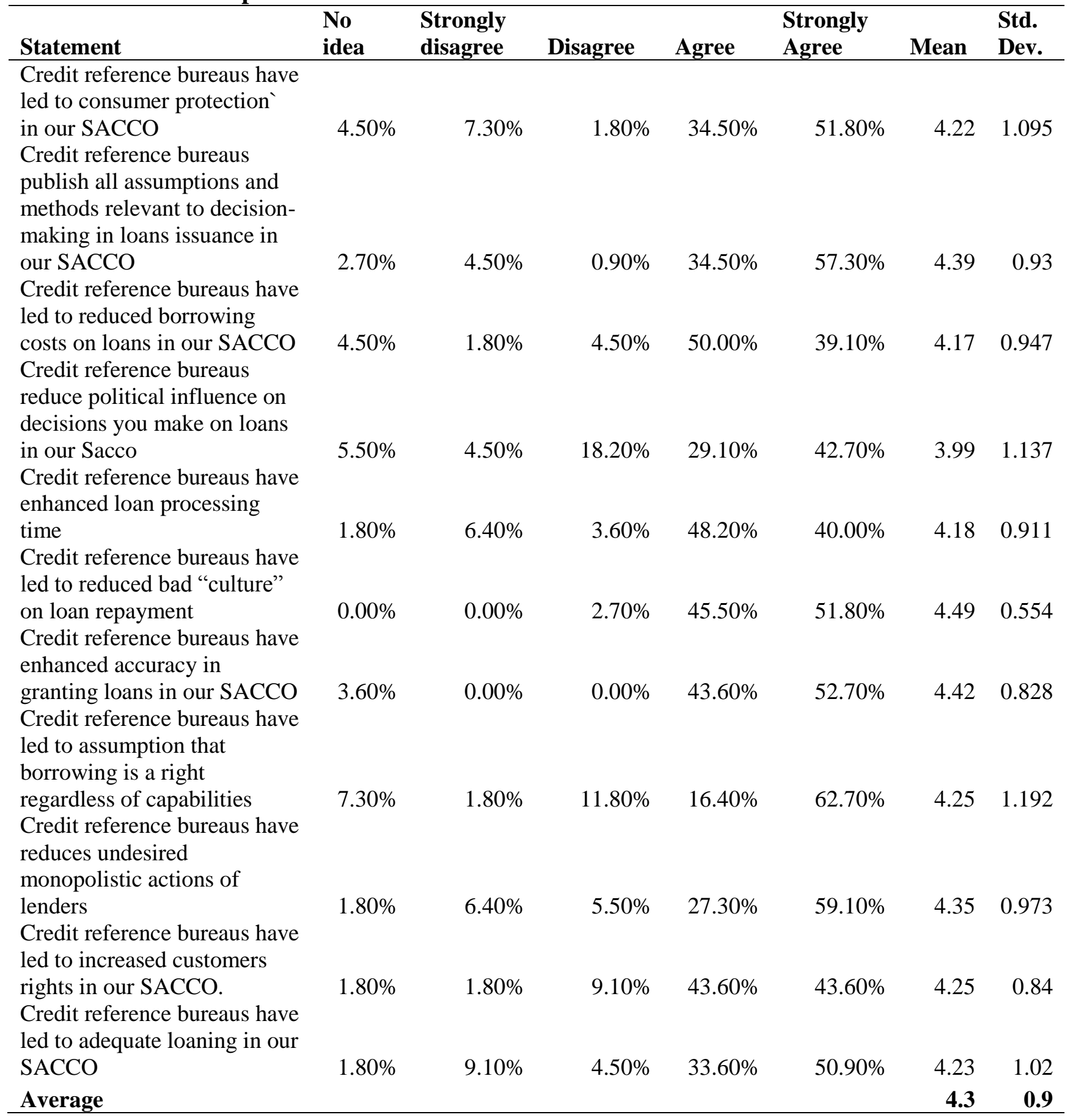


Results in table 6 indicated that 86.3 percent of the respondents agreed that Credit reference bureaus have led to consumer protection; 91.8 percent strongly agree that Credit reference bureaus publish all assumptions \& methods relevant to decision-making in loans issuance; 81.9 percent agreed that Credit reference bureaus have led to reduced borrowing costs on loans; 71.8 percent agreed that Credit reference bureaus reduce political influence on decisions you make on loans. 88.2 percent agreed that Credit reference bureaus have enhanced loan processing time. Chakazamba, et al., (2013) found that after the introduction of credit registries time taken in lending decisions reduced otherwise loan applicants took a lot of time before they could get responses.

97.3 percent agreed that Credit reference bureaus have led to reduced bad "culture" on loan repayment as Anderson (2007) found that with CRBs a culture of financial discipline will be installed since customers know that they will be monitored. 96.3 percent agreed that Credit reference bureaus have enhanced accuracy in granting loans. 71.9 percent agreed that Credit reference bureaus have led to assumption that borrowing is a right regardless of capabilities. The respondents indicate 86.4 percent agreed that Credit reference bureaus have reduces undesired monopolistic actions of lenders. Kohansal \& Mansoori (2009) found that monopoly power in credit markets often exercised by informal lenders, large transaction costs incurred by borrowers in applying for loans and moral hazard problems are the main causes of defaults. 87.2 percent agreed that Credit reference bureaus have led to increased customers' rights. Further, 20 percent agree, 84.5 percent agreed that Credit reference bureaus have led to adequate loaning. This is in agreement with Kioko (2014) that if loans increase they signal good performance.

Using a five point scale likert mean, the overall mean of the responses was 4.3 which indicates that majority of the respondents agreed to the statement of the questionnaire. Additionally, the standard deviation of 0.9 indicated that the responses were varied.

\subsection{Correlation Analysis}

Correlation analysis was conducted between Consumer protection function (independent variable) and financial performance (dependent variable). Results are presented in Table 7.

Table 7: Correlation matrix

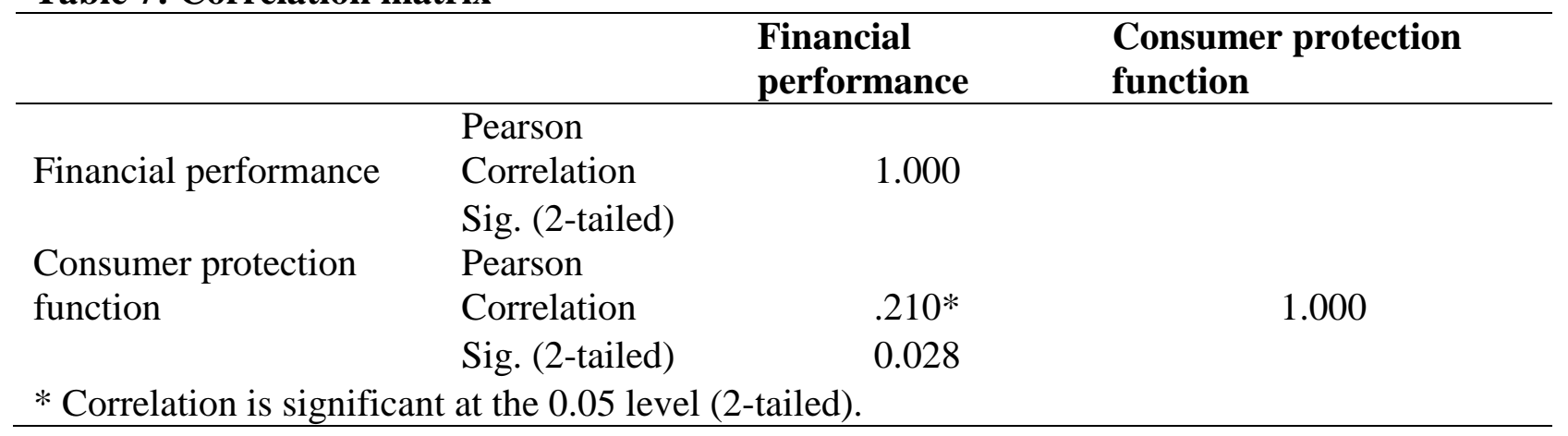

Results in Table 7 indicated that there was a positive and a significant association between Consumer protection function and Financial performance $(r=0.210, p=0.028)$. Information obtained from CRBs by financial institutions is used to ensure safety and soundness; and effective financial services. The shared information to borrowers restricts lending by financial 
institutions to only those customers they know (IMF, 2013). CRBs have the right to list borrowers for a period of five years if they default their loans so that they are restricted to be granted any further loans. With little credit rights banks compete hard in order to be the first bank to attract a borrower through loan pricing and avoid the lemon problem they would otherwise face. CRBs detail the manner in which data should be collected and handled by the CRBs to guarantee borrowers confidentiality. Better credit rights or information sharing lead to more economic growth (Boyd \& Hakenes, 2013).

\subsection{Regression Analysis}

The objective of the study was to establish the effect of Consumer protection function on financial performance of SACCOs in Kenya. Ordinary least square regression analysis was conducted and the result was represented in Table 8.

Table 8: Consumer protection function on financial performance

\begin{tabular}{lccccc}
\hline & \multicolumn{2}{l}{$\begin{array}{l}\text { Unstandardized } \\
\text { Coefficients }\end{array}$} & $\begin{array}{l}\text { Standardized } \\
\text { Coefficients }\end{array}$ & t & Sig. \\
\hline Variable & $\mathbf{B}$ & Std. Error & Beta & & \\
$\begin{array}{l}\text { Constant) } \\
\begin{array}{l}\text { Consumer protection } \\
\text { function }\end{array}\end{array}$ & 0.291 & 0.037 & & 7.783 & 0.000 \\
\hline
\end{tabular}

Table 8 showed that Consumer protection function was positively and significantly associated with financial performance $(\mathrm{r}=0.02, \mathrm{P}=0.028)$. Thus, a unitary percentage increase in Consumer protection function leads to an increase in financial performance by $2 \%$. Djankov, McLeish, \& Shleifer (2007) found that creditor rights are relatively more important to lending but also Acharya, Amihud \& Litov (2011) found that strong credit rights reduce the value of cooperation and increases risk of failure and the likelihood of crisis. On examining the relevance of credit reference bureaus and its effects on the financial performance of banks in Kenya, Alloyo (2013) showed that before commissioning of credit reference bureaus the semi-annual financial performance of banks was fairly constant. However, the financial performance increased slightly with commencement of credit reference bureaus. The findings also established that consumers and lenders find the credit reference bureaus useful in the financial industry in Kenya which will lead to a bigger credit market, lower default and interest rates, improved profitability for the financial institutions, increase price competitiveness of credit facilities, instill good credit behavior among lenders, improve pool of borrowers, expansion of lending and help improve access to credit in Kenya.

The specific model was;

$\mathrm{Y}=0.291+0.02 \mathrm{X}_{1}$

Where $Y=$ Financial Performance

$\mathrm{X}=$ Consumer protection function 


\subsection{Hypothesis Testing}

The hypothesis was tested by using simple linear regression (table 8 , above). The acceptance/rejection criteria was that, if the $\mathrm{p}$ value is greater than 0.05 , the Ho is not rejected but if it's less than 0.05 , the Ho fails to be accepted.

The null hypothesis was that Consumer protection function has no significant effect on financial performance of SACCOs in Kenya. Results in Table 8 above show that the p-value was $0.028<0.05$. This indicated that the null hypothesis was rejected Consumer protection function has a significant effect on financial performance of SACCOs in Kenya.

\subsection{Conclusions and Recommendations}

\subsection{Conclusions}

The study concludes that there is a significant and positive relationship between consumer protection function and financial performance thus the existence of credit reference bureaus was suitable for improving financial performance of SACCOs. This implies that that Credit reference bureaus have led to consumer protection and increased customers' rights. Similarly, credit reference bureaus have led to assumption that borrowing is a right regardless of capabilities. Credit reference bureaus have reduces undesired monopolistic actions of lenders. Lastly, credit reference bureaus have led to reduced bad "culture" on loan repayment.

Based on the correlation analysis consumer protection function and financial performance of SACCOs are positively and significantly associated. Regression analysis indicated that consumer protection function have a positive and significant effect on financial performance of SACCOs $(\mathrm{r}=0.02, \mathrm{P}=0.028)$. Thus, a unitary percentage increase in Consumer protection function leads to an increase in financial performance by $2 \%$. The hypothesis results indicated that there is a significant relationship between consumer protection function and financial performance of SACCOs in Kenya. The null hypothesis was therefore rejected hence consumer protection function has a significant effect on financial performance of SACCOs in Kenya.

\subsection{Recommendation}

Lenders should ensure that they have accurate information before listing the unworthy borrowers to avoid unnecessary legal battles which may affect performance as a measure for customer rights protection. 


\section{REFERENCES}

Alloyo, P. T. (2013). The Effect of Credit Reference Bureaus on the Financial Performance of Commercial Banks in Kenya. Nairobi: University of Nairobi.

Bercoff, J., Giovanni, G., \& Grimard, F. (2012). Argentinean Banks, Credit Growth and the Tequila Crisis: A Duration Analysis. Sau Paulo: Central Bank of Argentina.

Boyd, J. H., \& Hakenes, H. (2013). A Theory of Creditor Rights, Information Sharing and Bank Risk Taking. University of Bonn and MPI Bonn. Minnesota: Carlson School of Management.

CBK. (2012). Update on the Credit Information Sharing Project, Nairobi. Retrieved September 26, 2015, from Central Bank of Kenya: http://www.centralbank.go.ke.

CBK. (2013). Bank Supervision Annual Report 2013. Nairobi: Central Bank of Kenya.

Chakazamba, L., Matanda, E., \& Dube, H. (2013). The Impackt of Credit Bureaus on the Performance of Zimbabwean Financial Institutions. Journal of International Academic Research for Multi Disciplinary , I (10), 3-15.

Djankov, S., McLeish, C., \& Shleifer, A. (2007). Private Credit in 129 Countries. Journal of Financial Economics , 84 (2), 299-329.

Gaitho, N. W. (2013). Role of Credit Reference Bureaus on Credit Access in Kenya: A survey of Commercial Banks in Kenya. European Scientific Journal , IX (13), 1-14.

Kioko, C. (2014). Credit Information Sharing Influence on Performance of Licensed Deposit Taking Sacco Businesses in Kenya. The Strategic Journal Of Business \& Change Management, II (39), 1-18.

Kwambai, D., \& Wandera, M. (2013). Effects of Credit Information on Non-Performing Loans: The Case of Kenya Commercial Bank. European Scientific Journal , IX (13), 168-193.

Lin, C., Ma, Y., \& Song, F. (2012). What Drives Bank Operating Efficiency? The Role of Bank Competition and Credit Information Sharing. Research Handbook on International Governance, 87. 
Marcucci, J., \& Quagliariello, M. (2011). Is Bank Portfolio Risk Procyclical? Evidence from Italy Using a Vector Auto Regression. Journal of International Financial Markets, Institutions and Money, 18, 46-63.

SASRA. (2012). SACCO Societies Regulatory Authority. Nairobi: Government Printers.

SASRA. (2014). SACCO Societies Regulatory Authority. Nairobi: Government Printer.

Segita, M. A., Limo, C., Kibati, P., \& Muhanji, S. (2014). Asymmetry of Informatin on Credit Reference Bureaus for Bank Customers in Kenya: A case Study of Nakuru Town. Nakuru: Kabarak University.

Siwela, M. (2011). The Development of the Credit Reference System of Zambia. Lusaka: University of Zambia. 